\title{
PROWADZENIE CUDZYCH SPRAW BEZ ZLECENIA JAKO WYRAZ ZACHOWAŃ ALTRUISTYCZNYCH ${ }^{*}$
}

Nieprzewidywalność okoliczności, z którymi życie konfrontuje człowieka, sprawia czasami, że jest on bezradny i nie może właściwie zatroszczyć się o własne sprawy. Potrzeby związane z tego typu sytuacjami stały się impulsem do powstania negotiorum gestio - oryginalnej instytucji rzymskiego prawa prywatnego, umożliwiajacej osobie przychodzącej z pomocą dochodzenie zwrotu poczynionych wydatków, a osobie, której pomoc została udzielona, dochodzenie wydania osiagniętej korzyści. Instytucja ta stała się charakterystycznym elementem tradycji civil law.

Stąd też odzwierciedlająca ideę negotiorum gestio regulacja prowadzenia cudzych spraw bez zlecenia została wprowadzona do Kodeksu zobowiazań z 1933 r., a po niewielkich zmianach, także do obecnie obowiązującego Kodeksu cywilnego z 1964 r. Pomimo ponadosiemdziesięcioletniej obecności w polskim systemie prawnym jest ona praktycznie nieznana społeczeństwu, doktryna interesuje się nią w ograniczonym zakresie, a spory powstałe na jej gruncie niezwykle rzadko pojawiają się na wokandach. Dodatkowo, coraz bardziej dostępne i coraz doskonalsze stają się środki komunikacji i łączności, które ograniczają naszą bezradność. Wobec tego pojawia się pytanie, czy instytucja ta nadal jest potrzebna. Czy jej obecność w Kodeksie cywilnym nie jest jedynie wynikiem konserwatyzmu prawniczego?

$\mathrm{Z}$ drugiej strony na gruncie nauk humanistycznych i społecznych, szczególnie od drugiej połowy XX w., toczy się dyskusja dotycząca istnienia prawdziwego altruizmu. Powstaje wątpliwość, czy rzeczywiście słuszne jest, aby osoba przychodząca drugiemu z pomoca, nie będąc o to proszona, ani do tego zobowiązana, miała prawo do zwrotu wydatków. Dlatego też rodzą się pytania o to, czy ustawodawca powinien chronić postawy altruistyczne? Jeżeli tak, to w jakim stopniu? Czy instytucja prowadzenia cudzych spraw bez zlecenia przyczynia się do ich ochrony i jak z perspektywy dorobku nauk humanistycznych i społecznych należy ocenić rozwiązania przyjęte przez ustawodawcę?

\footnotetext{
* W artykule przedstawiona została część wniosków zawartych w pracy magisterskiej pt. „Altruizm w prawie zobowiązań: prowadzenie cudzych spraw bez zlecenia”, przygotowanej przez autorkę pod kierunkiem prof. dr. hab. Wojciecha Dajczaka. Praca ta została uhonorowana I nagrodą w konkursie im. prof. Kazimierza Kolańczyka na najlepsze prace magisterskie obronione na Wydziale Prawa i Administracji Uniwersytetu im. Adama Mickiewicza w roku akademickim 2012/2013.
} 


\section{ISTOTA ALTRUIZMU W ŚWIETLE DOROBKU NAUK HUMANISTYCZNYCH I SPOŁECZNYCH}

Chcąc udzielić odpowiedzi na podstawowe dla niniejszych rozważań pytania dotyczące altruizmu, należy w pierwszej kolejności prześledzić dyskusję, jaka od starożytności toczy się na gruncie filozofii - pytania dotyczące altruizmu i egoizmu są bowiem w istocie pytaniami o naturę człowieka. Dalej nieodzowne jest sięgnięcie do ustaleń językoznawczych, dających obraz tego, jakie znaczenia przypisuje się słowu „,altruizm” w języku polskim. Rozważania terminologiczne prowadzone są także w psychologii i socjologii, niemniej przede wszystkim nauki te dostarczaja opartej na badaniach empirycznych wiedzy o postawach pomocnych i ich znaczeniu zarówno dla jednostki, jak i społeczeństwa. Z uwagi na ograniczenia redakcyjne informacje zawarte poniżej tworza jedynie uproszczony szkic.

Przechodząc na grunt refleksji filozoficznej, należy zaznaczyć, że jej osią jest fundamentalne zagadnienie: czy człowiek jest zdolny do prawdziwej bezinteresowności? Podstawę większości poglądów ${ }^{1}$ stanowi przekonanie o egoistycznym charakterze natury ludzkiej. Jednakże część filozofów poprzestaje na twierdzeniu, że nie może istnieć coś takiego jak prawdziwy altruizm, a druga część dopuszcza współistnienie w człowieku pierwiastków popychających go do szlachetnej dobroczynności. W wielu wypowiedziach altruizm występuje jako element niezbędny do prawidłowego funkcjonowania społeczeństwa. Jeżeli już nie neguje się możliwości jego istnienia, to z reguły oceniany jest on pozytywnie i stanowi wartość wzbogacająca pojedynczego człowieka, jak i wspomagającą życie społeczne. Wydaje się, że nie ma podstaw do tego, by mówić o wyraźnej i ugruntowanej intuicji co do możliwości wystapienia postępu moralnego w wyniku promowania postaw altruistycznych. Niemniej trzeba zauważyć, iż taki pogląd jest obecny w dyskusji filozoficznej - można go dostrzec np. u stoików, u Johna Stuarta Milla, Woltera, Kanta, czy Comte’a. Wprost do takiej promocji, i to poprzez ustawodawstwo, nakłaniał Helvetius. Co jednak najbardziej znamienne, samo słowo „altruizm” ma właśnie filozoficzna proweniencję².

Pojawiające się przy głębszym namyśle trudności z precyzyjnym określeniem znaczenia tego słowa skłaniaja do przeprowadzenia analizy definicji słownikowych ${ }^{3}$. Wynika z niej po pierwsze, iż altruizm jest pewną trwałą re-

\footnotetext{
${ }^{1} \mathrm{Na}$ potrzeby niniejszego opracowania przeprowadzono analizę poglądów stoików, Epikura, Hobbesa, J. Locke'a, angielskich filozofów epoki oświecenia, Shaftesbury'ego, Butlera, Bernarda de Mandeville, D. Hume'a, A. Smitha, J. Benthama, J. Grote'a, J. S. Milla, H. Sidgwicka, Woltera, Helvetiusa, I. Kanta, A. Schopenhauera, M. Stirnera, A. Comte'a, H. Spencera, F. Nietzschego, H. Bergsona. Por. np. W. Tatarkiewicz, Historia filozofii, Warszawa 1983.

${ }^{2}$ W świetle ustaleń etymologicznych, „altruizm” (na wzór francuskiego égoïsme) stworzył w 1830 r. francuski filozof pozytywista August Comte.

${ }^{3} \mathrm{~W}$ niniejszym artykule prezentowane sa jedynie wnioski z analizy definicji w języku polskim (m.in. Trzaski, Everta i Michalskiego stownik języka polskiego, red. T. Lehr-Spławiński, t. 1, Warszawa 1935; Stownik języka polskiego, red. W. Doroszewski, t. 1, Warszawa 1964; Nowy stownik języka polskiego, red. E. Sobol, Warszawa 2002; Uniwersalny słownik języka polskiego, red. S. Dubisz, t. 1, Warszawa 2006).
} 
gułą zachowania, nastawieniem konkretnej osoby, prezentowana postawa. Z całą pewnością nie można nazwać altruizmem pojedynczego zachowania czy zespołu zachowań będących efektem doraźnej decyzji, a nie przyjętej „filozofii życia”. Po drugie, co częściowo wynika z poprzedniej myśli, altruizm jest reguła zachowania skierowaną nie względem wybranej osoby czy osób, ale względem ludzi - generalnie. Po trzecie, zakłada się przyrost określonego dobra po stronie drugiej osoby, a (co najmniej domyślnie) stratę po stronie altruisty. Problematyczne jest pytanie, jaką wielkość powinna mieć owa strata. Przegląd zwłaszcza współczesnych definicji prowadzi do wniosku, iż chodzi o poświęcanie się dla innych, życie dla nich, oddawanie im siebie samego.

Podobnie jak na gruncie językoznawczym, w psychologii prima facie nie sformułowano jednolitej definicji altruizmu. Pomimo istnienia rozbieżności między pozytywnymi definicjami, stanowisko w odniesieniu do definicji negatywnej jest jednolite i można je przedstawić następująco: „[...] prawdziwa prospołeczność/altruizm w znaczeniu psychologicznym to działanie na rzecz dobra innych, niemotywowane nagrodą zewnętrzną [...]"4.

Należy w tym miejscu dodać, iż określanie altruizmu czy egoizmu przymiotnikiem „psychologiczny” nie jest pozbawione znaczenia. W nauce wyróżnia się bowiem altruizm behawioralny (,zachowanie pomocne, które jest albo bardzo kosztowne dla pomagającego, albo nie przynosi mu żadnej korzyści osobistej”) i psychologiczny (,motywacja do zwiększania dobra innej osoby jako celu samego w sobie"6). Podział ten zwraca uwage na motywację do działania (wychodząc poza opis zewnętrznych skutków), która będąc jednym ze składników wskazanej wyżej definicji negatywnej, „historycznie jest dla altruizmu decydujaca"?.

Z punktu widzenia psychologii społecznej zjawisko altruizmu jest pożądane - korzystne zarówno dla jednostki (biorcy czy nawet w ostatecznym rozrachunku dawcy pomocy), jak i dla całego społeczeństwa. Badacze wyjaśniają jego istnienie za pomoca trzech teorii: teorii ewolucyjnej, teorii wymiany społecznej i teorii norm społecznych ${ }^{8}$. „Wspomniane teorie są wobec siebie komplementarne. Każda z nich skupia się na jednym z dostępnych poziomów funkcjonowania człowieka: biologicznym ${ }^{9}$, psychologicznym lub społecznym,

\footnotetext{
${ }^{4}$ Ł. Wojciechowski, Ewolucyjne widzenie altruizmu - od redukcjonizmu do..., w: D. Rutkowska, A. Szuster (red.), O różnych obliczach altruizmu, Warszawa 2008, s. 23.

5 The Encyclopedia of Positive Psychology, red. S. J. Lopez, t. 1, Malden 2009, s.v. altruism, s. 33 (tłum. własne).

6 Ibidem, s. 33 (tłum. własne).

7 The Corsini Encyclopedia of Psychology, red. I. B. Weiner, W. E. Craighead, t. 1, Hoboken 2010, s.v. altruism, s. 70-71 (tłum. własne).

8 Zob. D. G. Myers, Psychologia społeczna, Poznań 2003, s. 594-595.

${ }^{9}$ Warto zwrócić uwagę na koncepcje socjobiologiczne E. O. Wilsona (Sociobiology, 1975) i R. Dawkinsa (The Selfish Gene, 1976), którzy analizowali problem zachowań altruistycznych w perspektywie ewolucyjnej. Zdaniem Dawkinsa jakiekolwiek działanie, które z pozoru wydaje się altruistyczne, nie jest takim - służy tylko i wyłącznie utrwaleniu genów w następnych pokoleniach - zob. New Dictionary of the History of Ideas, red. M. C. Horowitz, t. 1, New York 2005, s.v. altruism, s. 52 .
} 
starając się w jego ramach wyjaśnić dwa rodzaje altruizmu: (1) altruizm podporządkowany regułom odwzajemniania i (2) altruizm bezwarunkowy"10.

Ponadto liczne eksperymenty dostarczyły wiedzy na temat uwarunkowań dotyczacych postaw altruistycznych. Przykładowo ustalono, że z reguły pomagamy tym, którzy nam pomogli, a gdy pozycja obu stron jest nierównorzędna - tym, którzy znaleźli się w trudnym położeniu bez własnej winy. Nie ulega wątpliwości, że jesteśmy bardziej skłonni pomagać osobom podobnym do nas wiekiem, wyglądem, prezentowanymi poglądami itd. Jak się okazało, niebagatelny wpływ na zachowania altruistyczne ma kontekst sytuacyjny. Poczynione obserwacje umożliwiły psychologom określenie sposobów służących rozwijaniu gotowości do niesienia pomocy - zarówno poprzez eliminowanie oporów przed pomaganiem, jak i kształtowanie altruizmu w procesie socjalizacji ${ }^{11}$ - wszak zachowania altruistyczne nie sa instynktowne.

W odniesieniu do wspomnianego procesu postuluje się, aby przeciwdziałać „moralnemu wyłączaniu”, które polega na wykluczaniu konkretnej osoby czy grupy osób z kręgu, do którego sami siebie zaliczamy, a w konsekwencji, na zaniechaniu stosowania do niej/do nich tych samych reguł i standardów moralnych. Jak wskazuja badania, istotnym orężem jest także tzw. modelowanie altruizmu (dostarczanie przykładów w relacjach rodzinnych, materiałach dydaktycznych czy w przestrzeni publicznej) oraz upowszechnianie informacji wyjaśniających funkcjonowanie mechanizmów z nim związanych ${ }^{12}$. Jednakże „jeśli chcemy nakłonić ludzi do altruistycznych czynów, powinniśmy [...] pamiętać o działaniu efektu nadmiernego uzasadnienia: kiedy wywieramy zbyt silny nacisk na człowieka, aby komuś pomógł, grożąc mu lub kusząc go nagrodami, niszczymy wewnętrzną radość z czynienia dobra. Jeżeli zaś dostarczamy ludziom zaledwie dostatecznego uzasadnienia dla ich altruistycznego postępowania, skłaniamy ich do przypisywania swego zachowania własnej altruistycznej motywacji. W efekcie wzmacnia się ich gotowość do pomagania"13.

Przechodzac na grunt socjologii, można dostrzec, że rozumienie altruizmu nie jest tu zupełnie klarowne. Niemniej w nauce tej zwraca się uwagę na niezmiernie ważny aspekt - kontekst, w którym pojawia się zachowanie pomocne. Uwzględnienie kontekstu (tzn. np. bliskości relacji dawca-biorca, historii dotychczasowych relacji) pozwala uzyskać większą poprawność wyników kwalifikacji danego zachowania jako altruistycznego bądź niealtruistycznego. Istotnie, wskazówka ta pozwala na skorygowanie mankamentów pojawiających się definicji.

Omawiana postawa oceniana jest pozytywnie i przypisuje się jej podstawowe znaczenie dla społeczeństwa, zaznaczając, że może mieć pewne niepożądane skutki oraz że nie wszystkie społeczeństwa będą miały do niej jednakowy stosunek (zależy on od cech danego społeczeństwa ukształtowanych przez warunki jego funkcjonowania) ${ }^{14}$.

10 D. G. Myers, op. cit., s. 595.

11 Zob. ibidem, s. 618-627.

12 Zob. ibidem.

13 Ibidem, s. 626.

14 Zob. The Social Science Encyclopedia, red. A. Kuper, J. Kuper, t. 1, London-New York 2004, s.v. altruism and cooperation, s. 24. 
Wiele miejsca poświęcono rozważaniom na temat norm społecznych, przez istnienie których wyjaśnia się zjawisko altruizmu (tzw. teoria norm społecznych) ${ }^{15}$. Normy te stanowia przyswajane w procesie socjalizacji nakazy, z których odczytujemy oczekiwania społeczeństwa wobec jednostki - jej powinności. W kontekście altruizmu wymienia się przede wszystkim dwie spośród nich - normę wzajemności ${ }^{16}$ i normę społecznej odpowiedzialności ${ }^{17}$.

Dorobek socjologii ${ }^{18}$ potwierdza wnioski częściowo już zasygnalizowane. W interesie społeczeństwa leży ochrona i promocja altruizmu. Jest to przedsięwzięcie racjonalne (z uwagi na konieczność wytworzenia i utrzymania prawidłowych relacji społecznych, uchronienia ich przed erozja), a także realistyczne, gdyż zostało wykazane doświadczalnie, że modelowanie, warunkowanie, wzmacnianie, czy instruowanie, które może być także efektem istnienia odpowiedniej regulacji prawnej, powinno przynieść pożądane i trwałe efekty. Takimi skutkami może być nie tylko lepsze funkcjonowanie społeczeństwa (zmniejszenie poziomu patologii $\left.{ }^{19}\right)$, wyższy poziom socjalizacji, ale także efektywny postęp moralny.

Powyższy przegląd nie daje jednak jasnej odpowiedzi na pytanie, czym jest altruizm. Wobec kontrowersji, czy zachowanie pomocne powinno pociagać ze sobą koszty, w jakiej wysokości, oraz w jakiej perspektywie (subiektywnej czy obiektywnej) i ewentualnie w relacji, do jakiego dobra mierzyć tę wysokość, a także czy jednym z elementów koniecznych jest odpowiednia motywacja, za najbardziej trafną uznaję definicję przyjmowaną w psychologii (,prawdziwa prospołeczność/altruizm w znaczeniu psychologicznym to działanie na rzecz dobra innych, niemotywowane nagrodą zewnętrzną") z pokreśleniem kluczowego znaczenia motywacji pomagajacego, i z uzupełnieniem dotyczącym konieczności uwzględniania kontekstu, w jakim zachowanie następuje (bliskość relacji i ich historia). Definicja ta wynika z doświadczenia, nie jest pojęciem abstrakcyjnym i podatnym na arbitralne kształtowanie. Poza tym jest to definicja najbardziej „kompromisowa”, likwidująca wątpliwości rodzące bezowocną dyskusję na temat istnienia „prawdziwego altruizmu”.

Co jednak kluczowe, z jednej strony biorąc pod uwagę ocenę roli altruizmu, a z drugiej za Sławomirą Wronkowską przyjmując, iż „prawo jest wyrazem

\footnotetext{
${ }^{15}$ Zob. D. G. Myers, op. cit., s. 594-595.

${ }^{16}$ Warto zwrócić uwagę na teorię wymiany społecznej P. M. Blaua, u którego „wymiana społeczna” dotyczy ,[...] dobrowolnych działań jednostek motywowanych ze strony innych wzajemnościa, która one zgodnie z oczekiwaniem mają wywołać i rzeczywiście zazwyczaj wywołują" - zob. Wspótczesne teorie socjologiczne, oprac. A. Jasińska-Kania, t. 1, Warszawa 2006, s. 84. Z zakresu tego pojęcia P. M. Blau wyłącza zachowania podjęte zgodnie ze zinternalizowanymi normami (także zachowania dobroczynne), niemniej wskazuje, że uległość wobec presji społeczeństwa może się wiązać z wymianą pośrednią.

${ }_{17}$ Zob. np. D. G. Myers, op. cit., s. 589-591; Encyclopedia of Sociology, red. E. F. Borgatta, t. 1, New York 1992, s.v. altruism, s. 63; J. P. Rushton, Altruism, Socialization and Society, Englewood Cliffs 1980, s. 41-51.

18 Jedna z najsłynniejszych socjologicznych koncepcji dotyczących altruizmu jest, przedstawiona przez É. Durkheima, koncepcja samobójstwa altruistycznego - zob. Samobójstwo: studium $z$ socjologii, Warszawa 2011.

19 Zob. np. J. P. Rushton, op. cit., s. 183-199.
} 
potrzeby [...] uporządkowania życia społecznego i poddania go pewnym regułom, by umożliwiało istnienie i możliwie należyte funkcjonowanie społeczności państwowej, bardzo przecież zróżnicowanej, której członkowie mają odmienne potrzeby i aspiracje, w których dochodzi do rozmaitych konfliktów i zagrożeń, zarówno biologicznej, jak i społecznej egzystencji grupy"20 - uważam, że ustawodawca powinien chronić postawy altruistyczne. Skuteczność takich instrumentów jak modelowanie, wzmacnianie czy instruowanie, pozwala przyjąć, że także prawo jest narzędziem zdatnym do realizacji tego celu.

Wydaje się, że właściwym instrumentem są właśnie normy prawa prywatnego, znajdujące zastosowanie $\mathrm{w}$ stosunkach pomiędzy równorzędnymi i wolnymi jednostkami, ponieważ stosunki te to w rzeczywistości „przestrzeń”, w której postawy altruistyczne występuja. Pojawić się może wątpliwość, czy skoro prawo prywatne ma służyć jednostce do realizacji jej własnych interesów, ma więc cel wyraźnie egoistyczny, jest właściwym środkiem ochrony postaw altruistycznych, i czy ze względu na wspomnianą specyfikę regulacja ta będzie rzeczywiście chroniła bezinteresowność. Watpliwość ta jest zupełnie zrozumiała, jednak należy pamiętać, że prawo prywatne od czasów rzymskich nie promowało skrajnego indywidualizmu - w Rzymie miało charakter bardziej solidarystyczny niż $\mathrm{w}$ świetle ideologii rewolucji francuskiej, która w tym wymiarze nie zdała egzaminu na przestrzeni XIX i XX w. Nadto pojęcie korzyści bywa rozumiane w prawie prywatnym szerzej niż tylko korzyść materialna (również np. zadowolenie, satysfakcja). Widoczne jest to chociażby w dyskusjach dotyczących zadośćuczynienia czy dopuszczalności umowy na rzecz osoby trzeciej.

Podejmując decyzję w przedmiocie preferowanego kształtu regulacji, ustawodawca powinien brać pod uwagę wypływające z kultury i zwyczajów nastawienie do ingerencji w cudzą sferę interesów oraz poziom zaufania społecznego. Należy pamiętać, że efektywność konkretnych instytucji będzie w dużej mierze uzależniona od poziomu świadomości prawnej, tzn. wiedzy o tego rodzaju regulacji i jej skutkach.

\section{PROWADZENIE CUDZYCH SPRAW BEZ ZLECENIA W POLSKIM KODEKSIE CYWILNYM Z 1964 R.}

Analiza prac przygotowawczych przedwojennej Komisji Kodyfikacyjnej prowadzi do wniosku, że recepcja zobowiązania z tytułu prowadzenia cudzych spraw bez zlecenia do Kodeksu zobowiązań motywowana była dwoma przyczynami: chęcią ochrony postaw altruistycznych i po drugie, obecnością tego źródła zobowiązania w kodeksach obowiązujących na terenie Polski ${ }^{21}$. Mając nawet na uwadze, że Kodeks zobowiązań miał być ustawą unifikacyjna, widać wyraźnie, że wprowadzenie omawianej regulacji było w znacznej mierze po-

${ }^{20}$ S. Wronkowska, w: eadem, M. Zmierczak (red.), Kompendium wiedzy o społeczeństwie, państwie i prawie, Warszawa 2007, s. 103.

${ }_{21}$ Zob. R. Longchamps de Bérier, Uzasadnienie projektu kodeksu zobowiazań z uwzględnieniem ostatecznego tekstu kodeksu: art. 1-167, Warszawa 1934, s. 165 i 167. 
dyktowane konserwatyzmem prawniczym. Wobec niewielkich różnic między regulacjami Kodeksu zobowiązań i Kodeksu cywilnego, to samo można powiedzieć o obecnie obowiąującym unormowaniu.

Z jurydycznego punktu widzenia obecność prowadzenia cudzych spraw bez zlecenia w Kodeksie zobowiąań była jednak w pewien sposób uzasadniona. Co prawda zakres zastosowania tej instytucji, niepokrywający się z zakresem zastosowania niesłusznego zbogacenia ${ }^{22}$ był bardzo wąski, to obowiązek respektowania woli i brak ograniczenia wysokości zwrotu wzbogacenia były i nadal sa argumentami o dużej doniosłości ${ }^{23}$. Ponadto, abstrahując od kwestii ochrony postaw altruistycznych, wydaje się, że wzgląd na bogactwo sytuacji, jakie przynosi życie (np. związanych z wystapieniem niebezpieczeństwa dla życia, zdrowia czy majątku oraz innych nadzwyczajnych okoliczności) dostarcza najważniejszego argumentu na rzecz utrzymania takich przepisów w mocy.

Przechodząc do oceny konkretnych rozwiązań przyjętych w ramach prowadzenia cudzych spraw bez zlecenia, warto wskazać, że wbrew pozorom jest to obszar, w którym występuje wiele dyskusyjnych zagadnień związanych m.in. z kwestia odpowiedzialności gestora, jego zdolności do czynności prawnych, z pojęciem „cudzej sprawy”, wymogiem działania „bez zlecenia”, czy wymogiem działania zgodnie z wyraźną lub domniemaną wolą osoby zainteresowanej. W dalszej części poddane analizie zostaną jedynie wybrane problemy, w sposób szczególny związane z uwarunkowaniami postaw pomocnych.

\section{Wymóg posiadania intencji działania w cudzej sprawie}

Jedna z wątpliwości dotyczy tego, czy do powstania zobowiązania z tytułu prowadzenia cudzych spraw bez zlecenia konieczne jest, aby osoba działajaca posiadała wolę/intencję działania w cudzej sprawie, a idąc dalej - aby posiadała wolę/intencję działania w interesie/na korzyść osoby trzeciej? Przemysław Drapała wskazuje, iż warunek istnienia woli działania dla drugiego, choć nie wynika wyraźnie z art. 752 k.c., jest powszechnie przyjmowany zarówno w judykaturze, jak i w doktrynie ${ }^{24}$.

Jednakże w doktrynie ów wymóg nie jest na ogół wyodrębniany, a przynajmniej nie tak wyraźnie, jak np. obowiązek działania zgodnie z prawdopodobną wolą osoby zainteresowanej. Ponadto mówi się niejasno raczej o wykonywaniu czynności „ze świadomościa, że działanie dotyczy sfery prawnej osoby trzeciej” ${ }^{25}$, o konieczności działania „ze świadomościa, iż sprawa, którą prowa-

22 Historyczne powiązanie zakresów bezpodstawnego wzbogacenia i prowadzenia cudzych spraw bez zlecenia jest widoczne szczególnie wyraźnie na gruncie prawa francuskiego; zob. np. R. Bout, La gestion d'affaires en droit français contemporain, Paris 1972, s. 23-45 i 99.

${ }^{23}$ Zob. W. Ludwiczak, Prowadzenie cudzych spraw bez zlecenia. Wybrane zagadnienia, Warszawa 1960 , s. 74-81.

${ }_{24}$ Zob. P. Drapała, Prowadzenie cudzych spraw bez zlecenia. Konstrukcja prawna, Warszawa 2010, s. 84; wyrok SN z 21 grudnia 1967 r., I CR 526/67, OSP 1969, nr 2, poz. 34; wyrok SN z 9 marca 2004 r., I CK 576/03, Lex, nr 183735.

25 L. Ogiegło, w: K. Pietrzykowski (red.), Kodeks cywilny. Komentarz, Warszawa 2003, dostęp poprzez System Informacji Prawnej Legalis, art. 752 pkt 2. 
dzi, nie jest jego własną" ${ }^{26}$, albo o tym, że sprawa musi być cudza obiektywnie i według intencji działającego, gdyż „ustawa chroni [...] jedynie altruistyczne intencje gestora" ${ }^{27}$. Świadomość natomiast, jak sam zauważa P. Drapała ${ }^{28}$, jest jedynie koniecznym, niemniej niewystarczajacym elementem składowym nastawienia wolicjonalnego.

Warto także zwrócić uwagę na słowa P. Drapały dotyczące motywacji gestora: „w piśmiennictwie polskim dominuje zapatrywanie, zgodnie z którym, motywacja prowadzacego sprawę bez zlecenia nie musi być altruistyczna. Wskazuje się, iż u podstaw podjęcia się prowadzenia cudzej sprawy mogą leżeć bardzo różne motywy, począwszy od uznawanych za aksjologicznie pozytywne (przyjaźń, sympatia dla drugiej osoby, wola niesienia pomocy innym), poprzez neutralne (negotiorum gestor podejmuje się dla drugiego niebezpiecznej czynności motywowany swoją skłonnością do ryzyka), po motywy niealtruistyczne (np. chęć doprowadzenia do sytuacji, w której dominus negotii będzie musiał zwrócić poniesione przez gestora wydatki i nakłady lub będzie "winny przysługę«" "29. Autor wskazuje, iż takie stanowisko jest uzasadnione z trzech powodów: ze względu na to, iż motywacja altruistyczna wcale nie stanowi dla osoby zainteresowanej lepszej niż obowiązki ustawowe gwarancji ochrony jej interesów; po drugie, nie ma znaczenia etyczna ocena czyjegoś działania, jeśli przyniesie ono korzyść osobie zainteresowanej; a po trzecie, ocena owej motywacji rodziłaby problemy. Zaznacza ponadto, iż taki pogląd wcale nie eliminuje możliwości rozpatrywania roszczeń gestora z punktu widzenia klauzul generalnych, np. klauzuli zawartej w art. 5 k.c. ${ }^{30}$

W kontekście powyższych analiz trzeba zaznaczyć, iż intencja przysporzenia korzyści drugiej osobie jest kluczowa dla kwalifikacji konkretnego zachowania jako altruistycznego, a przy istnieniu jedynie świadomości trudno o niej mówić. Podobnie sam wymóg działania z korzyścią nie jest wystarczający. Można działać z korzyścią dla kogoś, a nie mieć takiej intencji (altruizm behawioralny). $\mathrm{W}$ istocie utrzymywanie opisanego stanu prawnego otwiera drogę do zakwalifikowania jako negotiorum gestio przejawów egoizmu, a zatem jego ochrony i promowania. Korzyść osoby zainteresowanej może stać się środkiem do osiagnięcia swoich własnych celów. Czy takie zachowanie nie jest sprzeczne z zasadami współżycia społecznego, i nie powinno być uznane za nadużycie prawa (art. 5 k.c.)? Sygnalizowane powyżej dopuszczenie możliwości stosowania art. 5 k.c. nie uzdrawia sytuacji. Zawsze bowiem działanie w wyniku pobudek egoistycznych będzie prowadziło do wykorzystania drugiej osoby do realizacji własnych interesów. Ustawodawca nie powinien dopuszczać do sytuacji, w której stan rzeczy niezgodny z zasadami współżycia społecznego powstaje nie w wyniku nadużycia prawa, a korzystania z niego lege artis. Dodatkowo, dochodzi przez to do promowania zachowań wątpliwych moralnie,

\footnotetext{
${ }^{26}$ W. Dubis, w: E. Gniewek, P. Machnikowski (red.), Kodeks cywilny. Komentarz, Warszawa 2013, dostęp przez System Edukacji Prawnej Legalis, art. 752 pkt 5.

${ }^{27}$ Z. Radwański, J. Panowicz-Lipska, Zobowiazania - część szczegótowa, Warszawa 2010,

${ }^{28}$ Zob. P. Drapała, op. cit., s. 87.

${ }^{29}$ Ibidem, s. 89-90.

${ }^{30}$ Zob. ibidem, s. 90.
} s. 174 . 
co nie pozwala na efektywne modelowanie altruizmu (zły przykład także jest powielany).

Punkt widzenia, zgodnie z którym ocena etyczna nie ma znaczenia, gdyż podjęte działanie przynosi korzyść osobie zainteresowanej, nie jest właściwy. Nie należy patrzeć na tę kwestię wyłącznie przez pryzmat korzyści majątkowej. Oznaczałoby to zredukowanie funkcjonowania człowieka w społeczeństwie jedynie do wymiaru materialnego. Poza tym uszczerbku może doznać wzgląd na wolę osoby zainteresowanej - być może nie chciałaby osiagnąć tej korzyści, gdyby wiedziała, jaki jest kontekst jej przysporzenia. Warto tu zwrócić uwagę na orzeczenie z 17 marca 2004 r. ${ }^{31}$, w którym Sąd Najwyższy stwierdził: „[...] art. 752 k.c. nie stwarza podstaw do traktowania korzyści wyłącznie w kategorii zysku, lecz nakazuje rozważyć sytuację osoby zastępowanej z punktu widzenia szeroko pojętego jej interesu wyrażającego się nie tylko w kategoriach majattkowych".

W świetle dorobku nauk społecznych i racjonalności dowodowej, uważam, że najlepiej byłoby wymagać nie pozytywnego dowodu posiadania intencji altruistycznej, a dowodu na brak intencji egoistycznej jako przeważającego motywu działania. Warto w tym miejscu zwrócić uwagę na prawo francuskie, w którym wyodrębnia się przesłankę posiadania intencji altruistycznej, a także na doświadczenie francuskiej judykatury w badaniu motywacji gestora ${ }^{32}$. Pojęcie „korzyści” powinno być zatem rozumiane jako zaistnienie stanu rzeczy zgodnego z interesem (majątkowym i niemajątkowym) ${ }^{33}$ dominus negotii. W takim zakresie nie mieściłyby się sytuacje osiagnięcia korzyści majątkowej, do którego motywacją było stworzenie obowiązku „zwrócenia przysługi”.

\section{Wymóg działania z korzyścią dla osoby zainteresowanej}

Wokół kwestii korzyści istnieje jednak więcej kontrowersji. Pojawiają się one na gruncie rozważań dotyczących wymogu działania z korzyścią osoby zainteresowanej, który jest warunkiem istnienia zobowiązania (art. 752 k.c.).

Spór wiąże się m.in. z problemem oceny korzyści. Zgodnie z pierwszym z prezentowanych poglądów, powinno się ją oceniać obiektywnie - a nie z perspektywy gestora, czy z perspektywy osoby zainteresowanej. Podnosi się tu jednak zarzut, że uszczerbku mógłby niekiedy doznawać obowiązek działania zgodnie z wolą osoby zainteresowanej ${ }^{34}$. Drugi pogląd głosi, iż należy dokonywać oceny z punktu widzenia właśnie osoby zainteresowanej ${ }^{35}$. Co jednak, gdy gestor nie zna tego, dla kogo działa? ${ }^{36}$ Zgodnie z trzecim zapatrywaniem, korzyść musi istnieć zarówno z obiektywnego, jak i subiektywnego punktu widzenia osoby zainteresowanej. Na ogół jednak nie wskazuje się rozwiązania

${ }^{31}$ II CK 71/03, Lex, nr 172800.

${ }^{32}$ Zob. R. Bout, op. cit.

${ }^{33} \mathrm{~W}$ doktrynie przyjmuje się, iż przez pojęcie „korzyść” należy rozumieć zarówno korzyść majątkowa, jak i osobistą (np. ochrona dóbr osobistych) - zob. np. Z. Radwański, J. Panowicz-Lipska, op. cit., s. 175 .

${ }^{34}$ Zob. P. Drapała, op. cit., s. 164 i 165-166.

${ }^{35}$ Zob. wyrok SN z 17 marca 2004 r., II CK 71/03, Lex, nr 172800.

${ }^{36}$ Zob. P. Drapała, op. cit., s. 164 i 166. 
problemu powstającego w przypadku konfliktu między rozumieniem obiektywnym a subiektywnym. Zgodnie z propozycją P. Drapały najtrafniej byłoby dać pierwszeństwo woli osoby zainteresowanej, jeżeli jednak wola ta nie jest sprzeczna z prawem ani z zasadami współżycia społecznego ${ }^{37}$.

Moim zdaniem najtrafniejszy wydaje się trzeci z zaprezentowanych poglądów. De facto oznacza to zbliżenie do rozumienia subiektywnego, niemniej kombinacja tych perspektyw stanowi słuszne zrównoważenie ochrony obu stron zobowiązania.

W doktrynie nie ukształtowało się także jednolite stanowisko w kwestii momentu dokonywania oceny istnienia korzyści. Leopold Stecki pisze: „znaczne uzasadnienie wykazuje stanowisko, według którego dezyderat działania z korzyścią dla osoby zainteresowanej powinno się łączyć z poszczególnymi czynnościami podejmowanymi przez negotiorum gestora. Nie można wszak wymagać, aby ostateczny rezultat jego działań przyniósł korzyść tamtej osobie. Lansowanie takiego postulatu w sposób bezwzględny prowadziłoby wszak do nadania instytucji prowadzenia cudzych spraw bez zlecenia atrybutów zobowiązania rezultatu. Tymczasem na rozważanym odcinku życia społecznego mamy do czynienia z zobowiązaniem starannego działania"38. Odmienny pogląd można odnaleźć w podręczniku Zbigniewa Radwańskiego i Janiny Panowicz-Lipskiej ${ }^{39}$ oraz w komentarzach Wojciecha Dubisa ${ }^{40}$ i Leszka Ogiegły ${ }^{41}$. Powszechnie przyjmowane jest zapatrywanie, zgodnie z którym wystapienie korzyści jest warunkiem skuteczności roszczenia gestora o zwrot wydatków i nakładów, a także granicą wysokości tego świadczenia ${ }^{42}$.

Wobec zaprezentowanych powyżej wypowiedzi, należy zastanowić się, jak w tym aspekcie rozumiane jest pojęcie „korzyści”? Można dojść do wniosku, że co do zasady doktryna utożsamia korzyść ze skutkiem działania (tzn. jeśli osiagnięto zamierzony skutek, to powstała korzyść). Dostrzegalne jest to zwłaszcza przy uwzględnieniu wykładni art. 757 k.c., gdyż tak jak miało to początkowo miejsce na gruncie Kodeksu zobowiązań, o korzyści na gruncie art. 752 k.c. wnioskuje się a contrario z treści art. 757 (odnośny fragment tego przepisu brzmi „chociażby jego działanie nie odniosło skutku”). Przemysław Drapała konstatuje: „[...] ustawodawca uprzywilejował gestora działającego w celu odwrócenia grożącego innej osobie niebezpieczeństwa i ratowania jej dobra" 43 .

Międzywojenna doktryna skorygowała jednak rezultat wykładni gramatycznej podobnych treściowo przepisów, uznając, że nawet poza sytuacjami ratunkowymi, finalne wystapienie korzyści nie jest koniecznym warunkiem istnienia zobowiązania. Wydaje się, że współczesna doktryna nie dostrzega

37 Zob. ibidem, s. 164-167.

${ }^{38}$ L. Stecki, w: J. Rajski (red.), System prawa prywatnego, t. 7: Prawo zobowiazań - część szczegółowa, Warszawa 2011, s. 592.

39 Z. Radwański, J. Panowicz-Lipska, op. cit., s. 175.

${ }^{40}$ W. Dubis, op. cit., art. 752 pkt 6.

${ }^{41}$ L. Ogiegło, op. cit., art. 752 pkt 3.

${ }_{42}$ Zob. P. Drapała, op. cit., s. 165; L. Stecki, op. cit., s. 597; L. Ogiegło, op. cit., art. 753 pkt 7 ; W. Dubis, op. cit., art. 752 pkt 3.

${ }^{43}$ P. Drapała, op. cit., s. 207. 
owego konfliktu wartości, który widzieli prawnicy przedwojenni, albo świadomie przyjmuje antyaltruistyczne stanowisko, iż aby mówić o korzyści, musi wystapić zamierzony efekt działania w cudzej sprawie (poza sytuacją ratunkowa).

W dodatku korzyść stanowi nie tylko warunek, ale i ograniczenie wysokości zwrotu wydatków. Nie tylko z punktu widzenia ochrony postaw altruistycznych, ale także szacunku dla woli osoby zainteresowanej, uważam, że należałoby podążyć śladem zapatrywania ukształtowanego na gruncie Kodeksu zobowiązań i za odosobnionym poglądem L. Steckiego. Prowadzenie cudzych spraw bez zlecenia powinno być zobowiązaniem starannego działania, a nie rezultatu. Tym bardziej że - jak pisze P. Drapała - przyjęcie rozumienia korzyści jako skutku ,[...] różnicuje zarazem pozycję prawną gestora i przyjmujacego zlecenia, ten ostatni bowiem jest uprawniony do otrzymania zwrotu wydatków i nakładów niezależnie od wyniku dokonanych dla zleceniodawcy czynności" ${ }^{4}$.

Przerzucenie ciężaru ryzyka przedsięwzięcia na gestora jest wysoce zniechęcającym wymogiem i potencjalnie najpoważniejszą bariera. Poza tym z łatwościa można wyobrazić sobie sytuację, w której sama osoba zainteresowana chciałaby, aby działanie zostało podjęte pomimo ryzyka nieosiagnięcia sukcesu (np. próba sprowadzenia z zagranicy wrażliwego na transport i trudno dostępnego gatunku rośliny). Nie należy w takiej sytuacji uzależniać ochrony gestora od potwierdzenia osoby zainteresowanej, gdyż jest to uznaniowy akt jego woli i zmiana układu okoliczności nawet niezwiązanych z przeprowadzoną czynnościa, następczych czy chociażby czysto prywatnych, mogłaby spowodować brak takiego potwierdzenia. Obowiązek działania zgodnie z wola zainteresowanego i z należytą starannością stanowi dostateczne zabezpieczenie interesów drugiej strony zobowiązania.

Leopold Stecki postuluje takie rozumienia korzyści, które jest podobne do rozumienia ukształtowanego $\mathrm{w}$ prawie rzymskim ${ }^{45}$ czy francuskim $^{46}$, a które zbliżone byłoby raczej do pojęcia „wzbogacenia” ${ }^{47}$ (przy bezpodstawnym wzbogaceniu) wyjaśnianego następująco: „polega na uzyskaniu jakiejś korzyści majątkowej w dowolnej postaci. Może znaleźć wyraz w nabyciu jakichś praw lub powiększeniu ich zakresu [...], na umocnieniu istniejacych praw [...], na używaniu cudzych praw lub na korzystaniu z cudzych usług uzyskiwanych zazwyczaj odpłatnie, na zwolnieniu z długu lub na zniesieniu praw rzeczowych obciążających rzeczy wzbogaconego. Korzyści te mogą polegać nie tylko na powiększeniu aktywów majątku, lecz także na zmniejszeniu jego pasywów lub na zaoszczędzeniu wydatków" 48 .

Majac na uwadze rozważania z powyższego akapitu, postuluję, aby we wszystkich przypadkach negotiorum gestio (nie tylko objętych zakresem art. 757 k.c.), w zakresie majątkowego aspektu korzyści, przyjąć rozumienie poję-

\footnotetext{
44 Ibidem, s. 207-208.

${ }^{45}$ Zob. D. 3, 5, 9, 1.

${ }^{46}$ Zob. np. R. Cabrillac, Droit des obligations, Paris 2012, s. 174.

${ }^{47}$ Przynajmniej w kontekście korzyści majątkowej, gdyż jak wiemy, przez „korzyść” rozumiana jest także korzyść osobista.

${ }^{48}$ Z. Radwański, A. Olejniczak, Zobowiazania-część ogólna, Warszawa 2008, s. 285.
} 
cia „korzyść” zbliżone do pojęcia „wzbogacenie”, przy czym przyczyna takiego wzbogacenia powinno być zdarzenie, które obiektywnie może prowadzić do osiagnięcia zamierzonego skutku ingerencji. Aktualne oczywiście pozostaja inne warunki powstania zobowiązania. Postawa altruistyczna nie wymaga osiagnnięcia skutku, a jedynie czynienia wszystkiego, aby on wystapił.

Z kryterium korzyści łączą się pytania o to, jak należy podejść do przypadków ingerencji w cudze sprawy bez uzasadnionego powodu albo w trakcie nieobecności osoby zainteresowanej, czy w sytuacji, w której sama nie może działać. Jak wskazuje P. Drapała, „przyjęcie założenia, iż gestor może podjąć działanie dla innej osoby (w celu przysporzenia jej korzyści) dopiero po uprzednim ustaleniu, iż ta osoba sama nie jest w stanie zajać się sprawa, prowadziłoby do istotnego ograniczenia zakresu zastosowania negotiorum gestio i stanowiłoby czynnik demotywujący potencjalnych gestorów zwłaszcza w sytuacjach, gdy byliby zmuszeni do podjęcia szybkiej decyzji odnośnie do rozpoczęcia działania w cudzej sprawie (np. ratowania cudzej rzeczy przed uszkodzeniem)" ${ }^{49}$.

Tego rodzaju zapatrywanie nie jest jednak zasadne. Warunek, aby potencjalny gestor musiał najpierw ustalić, iż osoba zainteresowana sama nie jest w stanie zajacc się własną sprawa, stanowi znacznie słabszą barierę dla pożądanych ingerencji niż obowiązek doprowadzenia do powstania finalnej korzyści z działania (skutku), zwłaszcza przy dzisiejszych możliwościach technicznych. Jeżeli sytuacja ratunkowa wymaga działania na tyle pilnego, że ustalenie osoby zainteresowanej, czy skontaktowanie się z nią nie jest możliwe bez szkody np. dla rzeczy, i jeżeli osoby tej nie ma na miejscu zdarzenia, tzn. że nie jest ona w stanie sama zając się sprawą. W takim przypadku sprawdzenie okoliczności niemożności działania nie jest nadmiernie kłopotliwe ani czasochłonne, a sprzyja wyeliminowaniu z zakresu art. 752 k.c. zachowań niepożądanych, także egoistycznych. Takie rozumowanie w pewien sposób potwierdza wyrok Sądu Najwyższego z 18 marca 1981 r. ${ }^{50}$

\section{Roszczenia gestora}

W literaturze spotykany jest postulat stworzenia możliwości zasądzenia na rzecz gestora wynagrodzenia (gdyż de lege lata nie przewiduje się takiego roszczenia $^{51}$ ): „wydaje się, ze zasada bezpłatnego prowadzenia cudzej sprawy bez zlecenia wymaga odpowiedniego zweryfikowania. Pozostaje ona bowiem w pewnej kolizji z poczuciem słuszności (zasadami współżycia społecznego). Prowadzenie cudzej sprawy bez zlecenia obejmuje nieraz znaczny okres. Wiąże się ono często ze znacznym nakładem pracy działającej osoby. Występuja też przypadki, w których w wyniku tego zaangażowania się danej osoby istotnych ograniczeń doznaje sfera jej osobistych i majątkowych spraw. Bywa i tak, że prowadzenie cudzych spraw bez zlecenia, w ramach zawodowej działalności odnośnej osoby, oddziałuje redukująco na tamtą aktywność” ${ }^{52}$. Podobnie

${ }^{49}$ Zob. P. Drapała, op. cit., s. 124.

50 IV PR 59/81, OSNCP 1981, nr 9, poz. 179.

51 Zob. L. Ogiegło, op. cit., art. 753 pkt 5.

${ }^{52}$ L. Stecki, op. cit., s. 598. 
P. Drapała: „[...] wypada zauważyć, iż za odpłatnością działania gestora przemawiają argumenty natury aksjologicznej. Poświęcony przez gestora czas, wysiłek, podjęte starania, zaangażowanie własnych umiejętności a niekiedy wystawienie się na ryzyko, w związku z prowadzeniem cudzej sprawy ze względów etycznych, nie powinny pozostać bez jakiegokolwiek wynagrodzenia" ${ }^{53}$. Autor podnosi, iż przeciwnego stanowiska nie należy uzasadniać przy wykorzystaniu argumentu odwołującego się do altruizmu, gdyż jak to zostało wspomniane wcześniej, motywacja gestora nie ma znaczenia ${ }^{54}$.

Propozycję tę oceniam zdecydowanie negatywnie. Właśnie m.in. względy etyczne przemawiaja przeciwko przywołanemu postulatowi - wszak istota postaw altruistycznych jest dobrowolne ponoszenie pewnych kosztów. Dodatkowo należy zwrócić uwagę na doświadczenie prawa rzymskiego ${ }^{55}$, doświadczenie płynące z funkcjonowania salvage $\mathrm{w}$ systemie common law ${ }^{56}$, a także wskazać na zwrot w judykaturze francuskiej, gdzie ostatecznie nie przyjęto zasady wynagradzania profesjonalistów ${ }^{57}$. Przyznawanie wynagrodzeń prowadziłoby do „komercjalizacji” udzielania pomocy, a także zachęcałoby do zachowań niekorzystnych z punktu widzenia istnienia zasady swobody umów. Co więcej, jak to już zostało wspomniane, ustalenia z zakresu psychologii dowodza, iż takie rozwiązanie prowadzi do efektu nadmiernego uzasadnienia i eliminując zadowolenie z czynienia dobra, niszczy motywację altruistyczną.

\section{PODSUMOWANIE}

Analiza dorobku nauk humanistycznych i społecznych prowadzi do wniosku, że polski ustawodawca powinien w szerokim zakresie chronić i promować postawy altruistyczne. Może to czynić za pomocą regulacji prowadzenia cudzych spraw bez zlecenia. Pomimo że instytucja ta znalazła się w Kodeksie cywilnym, głównie przez wzgląd na tradycję, nadal występuje potrzeba uzasadniająca jej istnienie w polskim systemie prawnym.

$\mathrm{Na}$ podstawie art. 752-757 k.c. ochronie podlega szerokie spektrum zachowań, u których źródła może leżeć zarówno altruizm, jak i egoizm (zatem także egoizm może być modelowany). Stanowisko polskiego ustawodawcy, wbrew deklaracjom doktryny ${ }^{58}$ wcale nie jest przychylne względem osób działających z pobudek altruistycznych.

Korzystnym z tego punktu widzenia rozwiązaniem byłoby wprowadzenie kolejnego warunku powstania zobowiązania, tj. braku intencji egoistycznej jako przeważającego motywu działania. Ponadto przez pojęcie „korzyści” (na

${ }_{53}$ P. Drapała, op. cit., s. 221-222.

${ }^{54}$ Zob. ibidem, s. 222.

${ }_{55}$ Zob. np. R. Zimmermann, The Law of Obligations: Roman Foundations of the Civilian Tradition, Oxford 1996, s. 444.

${ }^{56}$ Zob. np. J. Kortmann, Altruism in Private Law. Liability for Nonfeasance and Negotiorum Gestio, Oxford - New York 2005, s. 158-163.

${ }^{57}$ Zob. np. R. Bout, op. cit., s. 94.

${ }^{58}$ Zob. np. L. Stecki, op. cit., s. 586; L. Ogiegło, op. cit., art. 752 pkt 1. 
gruncie i art. 752 i 757 k.c.) powinno się rozumieć zarówno korzyść materialna, jak i niematerialną (z zastrzeżeniem, że chodzi o wystapienie stanu rzeczy zgodnego zarówno z majątkowym, jak i niemajątkowym interesem dominus negotii). Rozumienie korzyści materialnej należy natomiast zbliżyć do rozumienia pojęcia „wzbogacenia”, przy czym przyczyną takiego wzbogacenia powinno być zdarzenie, które obiektywnie może prowadzić do osiagnięcia zamierzonego skutku ingerencji. Dodatkowo należy utrzymać istniejaccą de lege lata zasadę nieodpłatności działania gestora. Nadrzędnym postulatem, ale już nie legislacyjnym, jest zwiększenie świadomości prawnej Polaków, gdyż bez tego elementu ochrona ani promocja postaw altruistycznych w rozważany tutaj sposób nie będzie efektywna.

mgr Joanna Kruszyńska-Kola

Uniwersytet im. Adama Mickiewicza w Poznaniu

joanna.kruszynska@amu.edu.pl

\section{BENEVOLENT INTERVENTION IN ANOTHER'S AFFAIRS AS MANIFESTATION OF ALTRUISTIC BEHAVIOUR}

\section{Sum mary}

The first part of the paper presents the conclusions of research in the humanities and social sciences into the question of whether the legislator should protect altruism. Assuming a positive answer to the question and with the realisation that one of the ways of protecting altruism may be a legal institution based on the concept of negotiorum gestio, the second part of the paper deals with the analysis of benevolent intervention in another's affairs referred to the Polish Civil Code of 1964 (Articles 752-757).

It is stated that the main reason for incorporating this institution into the Code of Obligations of 1933 and then into the Civil Code was legal conservatism but there still exists a social need which justifies its existence in the Polish legal system. The general evaluation of benevolent intervention in another's affairs leads to the conclusion that contrary to the opinion of legal doctrine in Poland, the legislator is not favourable to those who help others from altruistic motives. Finally, three issues concerning the reward for the intervener, the requirements of having an intention to act in another's affairs and of acting to the benefit of another are subjected to a detailed evaluation. 